\title{
Nacionalismy utř́iěné a vysvětlené
}

\author{
JOHN A. HALL ${ }^{* *}$ \\ McGill University, Montreal, Canada \\ Nationalisms: Classified and Explained
}

\begin{abstract}
This paper argues against any general theory of nationalism on the grounds that the historical record shows several different types of the phenomenon in question. Seven types are distinguished. A particular character of the argument is the way in which political rather than socio-economic factors are taken into account. Sociologický časopis, 1995, Vol. 31 (No. 2: 149-168)
\end{abstract}

Porozumět nacionalismu je tak zřejmě naléhavou potřebou, že je nutné podat jasně vymezený přehled stavu diskuse mezi teoretiky tohoto tématu. Co vlastně víme o oné síle, jejíž dopad na naše století byl, v rozporu s očekáváními hlavních společenských teorií, větší než dopad jakékoli síly jiné?

Můj přehled bude spíš aktivní než pasivní. Použití množného čísla v titulu prozrazuje jednu základní tezi: jednotná, univerzální teorie nacionalismu není možná. Tak jako dějiné př́klady, i naše př́stupy musejí být rozmanité. Chci zdůraznit, že tímto nenavrhuji posun od univerzalismu $\mathrm{k}$ úplnému partikularismu, od obecné teorie $\mathrm{k}$ národním dějinám. Naopak, navržením různých ideálních typů nacionalismu, jejichž charakteristický vývoj a společenský základ si přiblížíme jménem, př́ikladem a, poněkud volněji, i typickým teoretikem, ${ }^{1}$ se dá nalézt střední cesta. Já se však pohybuji od trrídění $\mathrm{k}$ vysvětlení: má druhá teze je, že zákonitosti v pozadí různých typů nacionalismu jsou spíše politického než společenského rázu.

Analýza, kterou potřebuji, je podobná té, která se nyní používá při studiu ekonomického vývoje. Je obecně přijímáno, že existují různé způsoby dosažení ekonomického rozvoje [Zhao a Hall 1993]. Původní způsob nebyl dostatečně zachycen Maxem Weberem, ale vše svědčí pro jeho tvrzení, že byl původní v tom smyslu, že byl nevědomý a neplánovaný. Oproti tomu všechny ostatní formy ekonomického rozvoje byly imitativní a pokoušely se napodobit něco, čeho byly hlavní rysy dobře známy. Takové druhotné napodobení může, jako ve východní Asii, těžit z úplně jiných vlastností než

\footnotetext{
*) Raná verze této přednášky byla přednesena na konferenci o teoriích nacionalismu, kterou organizovala Středoevropská universita v Praze. Jsem zavázán Nicku Stargardtovi, Stephenu Graubardovi, Hudsonu Meadwellovi, Włodku Wesołowskému a, jako vždy, Michaelu Mannovi za připomínky a námitky, které při této př́iležitosti měli.

${ }^{* *}$ ) Veškerou korespondenci posílejte na adresu: Prof. John A. Hall, Department of Sociology, McGill University, Stephen Leacock Building, 855 Sherbrooke Street West, Montreal,

PQ H3A 2T7, Canada. Fax 0015143983403.

1) Typologie zde navržená zahrnuje a připojuje se k typologii Petera Altera z jeho vynikající, ale nedostatečně známé knihy Nationalism [Alter 1990]. Můj důkaz jako celek se podobá argumentu Wolfganga Mommsena [1990]. Určitá zde zmíněná volnost je důsledkem citování některých teoretiků ve spojení s jedním typem nacionalismu, i když se jejich př́stup týkal různých typů. Nepravosti zde spáchané budou uvedeny na pravou míru v průběhu eseje.
} 
z těch, z kterých se rodí objevy: na konformitě může nyní záležet více než kupř́kladu na bezuzdém individualismu [Abercrombie, Hill, Turner 1988]. Kromě toho máme nyní víc na paměti, že nedávný vývoj rozhodně není záležitostí jednotnou. Těžká industrializace imitátorů sklonku devatenáctého století - která se stala kvůli Leninovu obdivu k německému válečnému hospodářství obecným modelem státního socialismu - se ukazuje jako značně neefektivní, jakmile je státní merkantilismus vystřídán vzájemně provázaným světovým hospodářstvím, založeným na opravdové mezinárodní dělbě práce. Uvidíme, že nacionalismus má dějinná stadia, ačkoliv ne ve stejné míře jako ekonomický vývoj. Je však důležité zdůraznit ještě další analogii. Povaha stadií ekonomického vývoje je ovlivněná dějinami v úplně jiném smyslu. Je jimi ovlivněna ve smyslu idiosynkrazie či náhody. Přesněji řečeno, moderní světová politická ekonomie byla a je hluboce poznamenána politickým stylem Spojených států [Strange 1987]. Podobně i některé typy nacionalismu byly ovlivněny konkrétními historickými kombinacemi analytických faktorů, jejichž konstelace se již nemusí znovu opakovat.

\section{Nacionalismus definovaný, jeho modernita vyzdvižena}

Tak jako různost cest ještě nemusí znamenat nepř́tomnost jednotného významu ekonomického vývoje, tak ani rozmanitost nacionalismů neznemožnuje jednotnou definici.

O nacionalismu zde uvažuji velmi konvenčně [srv. Gellner 1983: 1. kap.; Breuilly 1982: 1. kap.; Hobsbawm nedat.: 9-13, 1. kap.]. Je to víra $\mathrm{v}$ nadřazenost určitého národa, skutečného či umělého. Vývoj této pozice směřuje $\mathrm{k}$ posunu od kulturních k politickým formám a $\mathrm{k}$ zahrnutí obyvatelstva, $\mathrm{k}$ jeho mobilizaci. Toto považuji za všeobecnou definici, ale je nutné povšimnout si dvou dalších předpokladů, které do značné míry předurčí klíčové otázky a problémy.

Za prvé, definice je často spojována s názorem, že existovala tři hlavní stadia nacionalismu: zakládání nových států $\mathrm{v}$ Latinské Americe na počátku devatenáctého století, rozširrení provedené Woodrowem Wilsonem ve Versailles, a ještě větší a podstatněji tvưrčí expanze mezinárodního rrádu v důsledku dekolonizace [Mayal 1990: 64]. ${ }^{2}$ Je nutné poznamenat něco $\mathrm{k}$ názoru, že nacionalismus vzkvétá $\mathrm{v}$ důsledku rozkladu impérií. Tento pohled nás vede $\mathrm{k}$ uvědomnění si toho, že rozpad ruského impéria znamená nástup čtvrté významé epochy $\mathrm{v}$ dějinách nacionalismu. Přesto však by ale všeobecná definice neměla být chápána jako paralelní s názorem, že nacionalismus je v nějakém absolutním smyslu spř́zněn se separatismem. Ba naopak - duch nacionalismu může ovládat státy již existující. Kdyby se např́íklad zmobilizovaly současné Spojené státy, a to bud' v důsledku neopatrné manipulace elity, anebo na základě pocitu vycházejícího zezdola, totiž přesvědčení, že Japonsko je ekonomický nepř́tel, pak by to také mělo být považováno za př́klad nacionalismu.

Za druhé, navzdory pracím Johna Armstronga a Anthonyho Smithe se vše zdá svědčit pro názor, že nacionalismus je věc novodobá [Armstrong 1982, Smith 1986]. Samozrejmě, že vždy existovaly rozdílné kultury a určité horní vrstvy měly pocit sdílené etnické solidarity. Ale síla idey nacionalismu - totiž, že by lidé měli kulturu sdílet a nechat si vládnout jen někým ze stejné kultury - se zdá být historicky nová. Hrubé schéma většiny společností $\mathrm{v}$ dějinách - nemajících prostředky efektivní komunikace a možnost levné přepravy - ukazuje, že většina lidí žila ve značně izolovaných sídlech a

2) Vadou na kráse této knihy je prohlášení, že ,již nejsou říše, které by se mohly hroutit, a proto je i možnost vzniku dalších států tímto způsobem velmi miziváa“. 
nebyla proto $\mathrm{s}$ to sdílet pocit společného osudu $\mathrm{s}$ lidmi, se kterými se nikdy nemohla setkat [Crone 1990, Mann 1986, Anderson 1983, Gellner 1983: 2. kap.]. V této souvislosti považuji za důležité poznamenat, že pocit sdíleného osudu přichází na scénu mnohem později, než si většina lidí uvědomuje, a to dokonce i v základních společnostech severozápadní Evropy. Často citované objevy Eugena Webera z knihy Peasants into Frenchmen byly nedávno překvapivě podpořeny Susan Cotts Watkinsovou, která dokázala, že vzorce rozmnožování v západní Evropě se staly národní záležitostí až na počátku dvacátého století [Weber 1979, Watkins 1991].

\section{Vývoj prùmyslu}

Ernest Gellner je teoretik, který si novodobost nacionalismu uvědomil snad nejvíce. ${ }^{3}$ Jeho př́nos ke studiu nacionalismu je a byl základní, a proto by bylo namístě - a nejen proto, že můj argument se od jeho liší - obrátit zde pozornost $\mathrm{k}$ jeho základní interpretaci nacionalismu, ačkoliv se tak odchýlíme od časové následnosti, která je jinak pro můj argument př́iznačná. Nacionalismus je Gellnerem viděn skrze vývoj průmyslu. Základem jeho teorie je tvrzení, že průmyslová společnost je závislá na sdílení kultury a jazyka a zcela nutně na sdílení širšího kulturního kódu. Zánik místních kultur v Alžírsku měl za následek útok na Francouze a Berbery a prosazování masového vzdělávání v arabštině. Ještě vážnější problémy a mnohem silnější odpor vyústily v př́ípad Nigérie. Zde mám dvě analytické poznámky. Na jedné straně se má za to, že průmyslová společnost závisí na schopnosti abstraktně komunikovat $\mathrm{s}$ lidmi $\mathrm{v}$ prostoru, $\mathrm{s}$ lidmi, které člověk nikdy nepotkal a nepotká. Na druhé straně je tu požadavek masivní společenské manipulace, protože ,nacionalismus není probouzením národů k sebevědomí: nacionalismus vynalézá národy tam, kde nejsou " [Gellner 1964: 169].

Útočnost tohoto tvrzení vedla Benedicta Andersona k závažné výtce: „Gellner tak moc touží ukázat, že se nacionalismus skrývá za falešným předstíráním, že ,vynález' má za ,padělání‘ a ,nepravost“ spíše než za ,představu“ a ,tvoření““ [Anderson 1991: 6]. Tato výtka je snad oprávněná, stejně jako př́ibuzný postřeh, že dějiny představ výstavbu národa ${ }^{4}$ usnadňují, ale nemělo by nás to odvést od základní správnosti Gellnerova postřehu. Neexistuje žádný pevný sociologický základ národa ${ }^{5}$ - není v jazyce, ani v náboženství, ani v etnickém původu, a Gellner má právo trvat na tom, že je těžší definovat národ než nacionalismus [Gellner 1983: passim, 1. kap.]. Nemáme důvod přijímat hypotézu o Šípkové Růžence, kterou nám předkládají nacionalisté, to jest názor, že nacionalismus je probuzení něčeho jsoucího, co doposud jen dř́malo. Gellnera je nutné hájit i $\mathrm{v}$ bodě druhém. Tento autor byl často napadán za to, že jeho pozice je funkcio-

3) Gellnerova nejranější formulace v jeho Thought and Change [Gellner 1964], kapitola sedmá. Mírně pozměněná verze jeho názoru byla publikována coby „Scale and Nation“ [Gellner 1973]. Nejúplněji vyjádřil svou pozici v Nations and Nationalism [Gellner 1983]. Významné posuny mezi oběma verzemi zachytil Anthony D. Smith [1984]. Gellnerova pozice se i nadále mění, jak můžeme pozorovat v [Gellner 1991, 1992, 1993].

4 ) Rozbory dřívějších představ jsou obsaženy v [Armstrong 1982, Smith 1986]. Srv. [Greenfield 1992]. Zdá se mi, že Gellner se nyní kloní k duchu tohoto názoru: jeho nejnovější, výše citované úvahy jasně rozlišují mezi národním obrozením v Německu a v Itálii, které již měly vyvinuté kultury, a obrozením v „,̌asové zóně“ dále na východ, kde se konstrukce začínala skoro z ničeho. 5) Za postřeh, že nacionalismus ,postrádá sociologický podklad a závisí na velkých politických plánech"vděčím Nicku Stargardtovi. 
nalistická. Je samozřejmě pravda, že funkcionalismus není a nemůže být z rozumového hlediska $\mathrm{v}$ pořádku: je nutné jakoukoliv teorii tohoto typu vyloučit. Logicky totiž funkcionalismus bere následek za př́činu, výraz společenské potřeby za důvod pro existenci institucí, které ji budou podporovat. Takový však není ani život - mám mnoho potřeb, z nichž mnohé zůstávají neuspokojeny - ani dějiny. Ale správné zpřesnění Gellnerovy teorie může poukázat na mechanismus vysvětlující proč pokusy vyhovět potřebě jsou úspěšné, a to zaručuje, že teorie může fungovat. Mechanismus je jednoduchý. Mnozí nacionalističtí vůdci v dvacátém století si byli vědomi spojení popsaného Gellnerem: jsou to inovátoři vědomí si toho, jak se vytváří průmyslová společnost. Snaží se rozdrobit ostrůvky tradičního řádu, aby vytvořili společnou kulturu schopnou integrovat veškeré obyvatelstvo. Daniel Patrick Moynihan, bývalý americký vyslanec ve Spojených národech, si to uvědomil ve své známé námitce, že mnozí nacionalisté třetího světa byli vzděláni na London School of Economics. Jomo Kenyatta, bývalý prezident Keni, může zajisté sloužit za př́íklad tohoto typu nacionalismu, a touto školou prošel nikdo menší než Bronislaw Malinowski, známý britský antropolog. ${ }^{6}$ Zajímavá je poznámka Jadwigy Staniszkis v Dynamics of the Breakthrough in Eastern Europe, kde se praví, že Alexander Jakovlev změnil svůj názor na národnostní otázku v bývalém Sovětském svazu, protože četba Gellnera ho přesvědčila, že nacionalismus je nutno respektovat, aby bylo možné dosáhnout kapitalistického vývoje [Staniszkis 1991: 294]. Toto je snad reálnější podpora Gellnerovy teorie, než by byla př́má tvorba důkazů! Ale to jen na okraj. Obecné tvrzení, kterého se chci držet, je, že Gellnerovo vylíčení tohoto typu nacionalismu je velmi úspěšné: ve vysvětlování třetího typu popisovaného nacionalismu jde do hloubky. Možná, že teorie vznikala v dobách, kdy Gellner pobýval v severní Africe v padesátých a šedesátých letech: je to ten druh zkušenosti, který se člověk snaží nějak si vysvětlit.

\section{Klasické vzorce}

\section{Vývoj nespoleèenské spoleènosti}

Jeden z důvodů, proč Gellnerova teorie není opravdu obecná, je, že se jí nedaří vysvětlit první výskyt nacionalismu v Británii a ve Francii v osmnáctém století. Důvod selhání je nasnadě: nacionalistické nálady se objevují před nástupem průmyslu. Tento typ nacionalismu se dá vysvětlovat jako vývoj nespolečenské společnosti, což je výraz Immanuela Kanta poukazující $\mathrm{k}$ multipolaritě, jejíž výskyt v severozápadní Evropě je v rámci naší civilizace něčím ojedinělým, která vedla $\mathrm{k}$ nekonečnému soupeření mezi státy [Hall 1985]. Obecnou povahu tohoto systému nejlépe popsal německý historik Otto Hintze a sociolog Charles Tilly [Hintze 1975, Tilly 1990, srv. Mann 1986]. Jejich závěr je, že války tvoří státy ve stejné míře, $v$ jaké státy vedou války. Neustávající soutěžení mezi státy vede k závodům ve zbrojení, které vyžadují víc a víc pěněz. Monarchové jsou tak nuceni nejen k pasivní nadvládě různých kulturních skupin na svých územích, ale i k větší interakci s nimi, nutné k tomu, aby od nich získali větší prostředky. Jeden ze způsobů získávání prostředků bylo zabezpečení justičních služeb. Další se děl skrze vzrůstající teritorializaci společenského života: ukázkou tohoto byla například narůstající schopnost dát řád, to jest, mít úspěšný nárok na monopol na násilí; byl jím i začínající ekonomický

\footnotetext{
6) Breuilly [1982] nabízí několik zajímavých poznámek o Kenyattovi. Podobně zaměřený článek, přesvědčivý a zneklidňující, napsala Susan Pederson [1991]. 
nacionalismus, který zvýšil cla a dovozní přirážky, na které se monarchové spoléhali. V delší časové perspektivě byly vojensky nejúspěšnější ty státy, které svá území zkonsolidovaly do jednotného celku. Takové národní státy často čerpaly sílu ze spolupráce s občanskými společnostmi, které nemohly plně kontrolovat - nepř́itomnost velké despotické moci zapř́íčinila vzrůst dosahu jejich infrastruktury. ${ }^{7}$

Typicky brilatní esej Michaela Manna, teoretika tohoto typu nacionalismu, začíná poznámkou, že osmnácté století přineslo nezanedbatelný nárůst komunikativních schopností občanské společnosti [Mann 1992, srv. Mann 1993]. Tyto se v Anglii tvořily zdola - nástupem ojedinělé předprůmyslové obchodní revoluce - a na pevnině shora vojenskými a ekonomickými požadavky osvíceného absolutismu. Tím byl zároveň umožněn vstup dalších národů na politickou scénu, což bylo značně v nesouladu s očekáváními takových vedoucích teoretiků, jakými byli např́iklad Adam Smith či David Hume. Jeden takový vstup vedl k vytvoření Spojených států, jejich politická kultura zůstala překvapivě univerzalistická i přes posun od „národů“ $\mathrm{k}$ „národu“ v klíčových zakládajících dokumentech z let 1776 a 1789. Francouzská revoluce byla také univerzalistická, bereme-li v úvahu, že si člověk mohl zvolit stát se Francouzem, ale celek, k němuž lidé přináleželi, byl jasně celkem jediného národa - s tím, že někteří jakobíni odmítali věrit komukoli, kdo se nenaučil francouzsky [Hobsbawm nedat.: 18-23].

Toto soustředění na národ se dá nejlépe vysvětlit tím, že občanská společnost zvětšila své možnosti právě $\mathrm{v}$ době, kdy Evropa byla rozdělena Atlantickou válkou, to jest zhoubným zápasem mezi Anglií a Francií během dlouhého osmnáctého století. Státy byly nuceny čerpat ze svých společností dříve nemyslitelné peněžní obnosy. ${ }^{8}$ Jedním z důsledků byla státní reforma, tedy konec „staré korupce“ v Británii a revoluce ve Francii. Dalším důsledkem byl nástup nacionalismu. Je zcela zásadní, že tyto procesy byly vzájemně propojeny a že zápas o reprezentaci nastolil otázku identity.

Velmi plastický obraz těchto procesů, vznikajících zdola i shora, tak jak probíhaly v Anglii, nám podává Linda Colley. Byla to velmi spletitá záležitost. Britský nacionalismus tu byl určitě jako první. Byl založen na představě protestantského národa napadeného evropskými katolickými monarchiemi [Colley 1992: 18]. Ale byl tu i anglický nacionalismus, často namířený proti Skotům - v neposlední řadě i kvůli tomu, že spojením s Británií tolik získali [Ibid.: 117-132]. John Wilkes je v mnoha směrech nejlepším představitelem takového nacionalismu [Brewer 1972]. Byl obhájcem nevybíravých způsobů Johna Bulla, rostbeefu, yorkshirského pudingu a svobod z roku 1688. Je naprosto charakteristické, že typická skupina zastánců Johna Wilkese se v roce 1768 sešla v taverně pojmenované po Vilémovi Oranžském ještě předtím, než začali hlasovat pro svého hrdinu pod vlajkou Magny Charty a Výčtu svobod; stejné množství wilkitských popěvků se zpívalo na melodii Rule Britannia jako na God Save the King. ${ }^{9}$ Toto všechno bylo samozřejmě dáváno do kontrastu se zjemnělou vyumělkovaností francouzské šlechty a o něco později i s geopolitickou rozpínavostí Napoleonovou. Sotva nás potom překvapí, že Francouzi na toto odpověděli vytvořením představy zrádného Albionu.

7) Tyto dimenze státní moci popsal Michael Mann [1984]. K pokusu odstranit nejasnosti tohoto tř́dění a posunout je dále, viz John A. Hall, 1993).

8) Podrobnosti jsou k nahlédnutí v tabulkách v [Mann 1993].

9) Tyto podrobnosti jsou převzaty z [Colley 1992: 111,112]. 


\section{Revoluce shora}

Zatímco nemůže být pochyb o dopadu představ o společenské mobilitě, jak ji reprezentoval Napoleon, k dalšímu typu nacionalismu, revoluci shora, můžeme nejlépe přistoupit pomocí poukazu na nedávné studie strategie francouzské armády [Blanning 1983, Schama 1977]. ${ }^{10}$ Není to tak, jak se do nedávna věřilo, že by francouzské armády úmyslně šírily nacionalismus. Naopak, fiskální krize francouzského státu způsobila, že armády se značně obohacovaly pleněním území jimi dobytých - a pokračovaly v tom po celá léta, kdy tato území musela za okupující francouzské jednotky platit. Francouzská nadvláda byla imperiální, a proto také vedla k nacionalistickým reakcím.

Pojem revoluce shora je samozřejmě převzat z Social Origins of Dictatorship and Democracy Barringtona Moora [1966]. Je ho zde užito k poukázání na typ nacionalismu, $\mathrm{k}$ němuž dospěly státy $\mathrm{s}$ vlastními dějinami, které se rozhodly změnit společenskou strukturu v zájmu vlastního přežití. To znamená, že se i zde jedná o zápolení mezi státy, stejně jako u předešlého typu, ale společenský základ tohoto typu nacionalismu je značně odlišný.Tento třetí typ nacionalismu byl nejlépe popsán Johnem Breuillym $\mathrm{v}$ jeho pojednání o reformátorech Meidži, jakožto reakci na vpád velitele Perryho, o jejich pruských předchůdcích a jejich reakci na možnost, že by pruský stát mohl v podstatě zaniknout po porážce u Jeny a Auerstadtu. ${ }^{11}$

Za ztělesnění takového nacionalismu mám Carla von Clausewitz, člena kroužku, který zahrnoval Scharnhorsta a Gneisenaua, ale spíše známého jako teoretika války. ${ }^{12}$ Této teorie bylo zapotřebí, když se v roce 1793 objevila síla:

„která se vymykala možnostem představivosti. Najednou se válka opět stala záležitostí národa - národa třicetimiliónového, v němž se každý cítíl být občanem... Národ se stal účastníkem války: místo vlád a armád jako doposud, plná síla národa byla vržena na váhy. Zdroje a úsilí nyní použitelné překročily veškeré obvyklé hranice: nic nyní nestálo v cestě síle, jíž mohla být válka vedena..." [Clausewitz 1976: 591-592].

Diagnóza, kterou provedli reformátoři po své vlastní porážce, podtrhla potřebu úplné proměny společnosti, která byla $\mathrm{k}$ přežití Pruska nutná. Profesionální armády Friedricha Velikého by nebyly s to postavit se občanům ve zbrani. Bylo rovněž nutné zrušit feudalismus a uvažovat o vyzbrojení obyvatelstva, aby bylo možné něco jako španělský gerilový odpor. To se Bedřichu Vilémovi III. př́iliš nelíbilo, ale omezení uvalené na Clausewitzův postup bylo umožněné a zdůvodněné něčím jiným. V roce 1812 totiž Prusko nakrátko uzavřelo mír s Napoleonem. Clausewitz, pobouřen uzavřením míru s národním nepř́telem, opustil důstojnickou službu a bojoval v ruské armádě proti Francouzům. Toto vše snad odráží fakt, že Clausewitz byl outsider. Je možná důležité i to, že Clausewitzova rodina nepatřila $\mathrm{k}$ vysoké šlechtě. On sám byl závislý na státní službě stejně jako méně významný samuraj restaurace Meidži [Breuilly 1982, kap. 15]. Ale kdyby tehdy starý režim vyhrál - vyděšený mobilizací lidu, k níž vedla provolání k národu - pak by dlouhodobě bylo Německo vytvořeno na základě revoluce shora.

\footnotetext{
10) Na podobné téma obecněji viz [Kaiser 1990].

11) [Breuilly 1982, kap. 9 a 13; Alter 1990: 34-37]. Oba dávají přednost výrazu „,reformní nacionalismus.“

12) Tento odstavec vděčí za mnohé vynikající práci Petera Pareta [1976]. 


\section{Touha a strach požehnaný pøíležitostí}

Vytvoření úplně nových států $\mathrm{v}$ Latinské Americe vyplynulo $\mathrm{z}$ velmi odlišného typu nacionalismu - zajímavé směsky touhy a strachu požehnané prŕležitostí - který je představován Simonem Bolívarem a dobře popsán Johnem Lynchem. ${ }^{13}$ Touha po nezávislosti plynula ze dvou zdrojů. Na jedné straně, ideály osvícenství, přicházející spíše ze Spojených států (jejichž role jako vzoru se nedá přecenit) než ze Španělska, uvedly do pohybu ideály svobody, rozumu a pořádku. Ještě mnohem významnější, na straně druhé, bylo však zklámání metropolí, zkorumpovanou a zároveň nedostatečně rozvinutou. Byl tu ekonomický prvek. Španělsko požadovalo od svých kolonií dodávky zlata a stříbra a chtělo, aby odebíraly jeho vlastní výrobky. Tím stále více narušovalo místní ekonomický vývoj a nepomohla tomu ani jeho účast $\mathrm{v}$ evropské válce, která ještě více zvýšila jeho fiskální potřeby. Po dlouhou dobu byl trh zcela ovládán španělskou elitou, která předražovala zboží dovážené a podceňovala zboží vyvážené. Další prvek byl společenský. Pokusy o zvýšení kontroly posíláním důstojníků z Evropy byly zvláště ponižující pro místní kreoly, jejichž úroveň vzdělání a mravů byla mnohem vyšší: „nejnižší, nevzdělaný a nekulturní Evropan“, napsal Alexander von Humboldt, „se má za nadřazeného bělochovi narozenému v Novém světě“ [Lynch 1987: 25]. K těmto pocitům přistupoval strach. Kreolští plantážníci byli malou menšinou ovládající většinu otroků a Indiánů, na jejichž pokojnosti byli závislí. Povstání Tupac Amuru jim ukázalo nebezpečí zpochybnění jejich privilegií ve vlastní zemi, ale ještě víc to byl Touissant l'Ouverture a jeho šíření hesel Francouzské revoluce, co je doopravdy vyděsilo. Jejich náklonnost

$\mathrm{k}$ heslům osvícenství nešla až $\mathrm{k}$ tomu, aby se byli ochotni smiřovat se ztrátou půdy či dokonce s vlastním zánikem. Tudíž jejich vlastní nacionalistické revoluce v prvních letech devatenáctého století - náhle umožněné Nelsonovým rozchodem s Pyrenejským poloostrovem a Napoleonovým vpádem - byly společensky mimořádně konzervativní. Zatímco logika procesu vyžadovala vytvoření jednotlivých států, bylo nutné vyhnout se všemi možnými prostředky mobilizaci obyvatelstva, která je jinak pro nacionalistickou politiku charakteristická. ${ }^{14}$ Tato segmentace společenského života zůstala pro Latinskou Ameriku typická, určitě i z toho důvodu, že relativní nepřítomnost geopolitického konfliktu netlačila a netlačí státy k většímu rozvoji infrastruktury [Holsti 1993].

\section{Nacionalismus risorgimenta}

Oproti tomu, co nás zaráží na nacionalismu risorgimenta - alespoň na první pohled - je, že vzniká ze zdola. Tento typ nacionalismu je neobyčejně dobře znám, a to v neposlední řadě díky výkladu Miroslava Hrocha v jeho Social Preconditions of National Revival in Europe, kde se zabývá třístupňovým vývojem od sběratelů folkloru, přes ideology nacionalismu, až k závěrečnému stádiu, kdy se kulturní obrození stává politickým

13) Zde jsem se nejvíce opíral o práci Gerharda Masura [1969], Johna Lynche [1973], a L. Bethella [1987]. José Merquior [1981] poznamenal již před nějakou dobou, že Gellnerova teorie nacionalismu nepodává vysvětlení první velké vlny tvorby států; Gellner to v Nations and Nationalism [1983] připouští na straně 135. První pokus učinit události v Latinské Americe středem studia nacionalismu učinil Benedict Anderson: upravené vydání Imagined Communities [1991] přináší pozměněný název čtvrté kapitoly - Kreolští průkopníci - a snaží se vyzdvihnout tuto dějinnou zkušennost.

14) Tento postřeh o vývoji učinil Anderson v Imagined Communities [1991], kapitola čtvrtá. 
nárokem [Hroch 1985]. ${ }^{15}$ Hnutí zdola bylo živeno dvěma silami. Za prvé, v devatenáctém století v Evropě přibylo vzdělaných lidí. Tento nárůst začal ještě předtím, než státy začaly usilovat o normativní integraci na vlastním území [O’Boyle 1970]. Za druhé, ekonomický vývoj měl za následek stěhování do měst: zánik tradičních segmentárních kultur učinil z lidí snadnou kořist nacionalistické propagandy. ${ }^{16} \mathrm{O}$ tomto typu nacionalismu je nutné poznamenat, že si zaslouží být klasifikován jako liberální: vyzdvihoval spíše občanskou př́slušnost $\mathrm{v}$ rámci demokratického režimu než etnicitu.

K nacionalistům tohoto typu se řadí John Stuart Mill i Mazzini a spojení jejich jmen napovídá, že tato doba vkládala naděje $\mathrm{v}$ to, že osvobození utlačovaných povede $\mathrm{k}$ trvalé vládě míru. ${ }^{17}$ Jejich jednotlivé vize jsou pozoruhodně nevinné - i ony však vedly k otřesům, když nehistorické národy (nejznáměji Irové) začali trvat na svém právu na stát.

Hrochova obdivuhodná fenomenologie nacionalismu neř́ká moc o tom, kde je přechod mezi kulturním a politickým nacionalismem. Ale není těžké jej vidět, když nastává, zvláště podíváme-li se na osudy Františka Palackého, českého historika, který následoval Herdera v tom, že viděl Čechy jako mírumilovný národ utlačovaný jak Němci, tak Mad'ary. ${ }^{18}$ Palacký začal pracovat pro České museum ve třicátých letech minulého století a své velké dějiny začal psát německy. Ve čtyřicátých letech jej však sílící protiněmecké nálady, plynoucí ze státního pokusu učinit němčinu úředním jazykem, vedly $\mathrm{k}$ tomu, že pokračoval česky. Byly to však až události roku 1848 , které ho přinutily zabývat se politikou. Čechové se odmítli přidat k Národnímu shromáždění ve Frankfurtu; cítili se ohroženi plány tam osnovanými - báli se, že by mohly vést $\mathrm{k}$ jejich kulturní porážce. Místo toho se účastnili protestního setkání v Praze, které jasně zdůraznilo, že Slovanům, nacházejícím se mezi Ruskem a Německem, kynou nejlepší vyhlídky u Habsburků. ${ }^{19}$

Zamyšlení nad touto epizodou vede ku dvěma analytickým poznámkám. Za prvé, posun od kulturního k politickému nacionalismu byl umožněn omezenou společenskou mobilitou. Neměli bychom se na to dívat jako na čistě ekonomickou záležitost - jak moudře praví Ernest Gellner - jako kdyby se lidé stávali nacionalisty jen proto, aby získali lepší pracovní místa, ačkoliv i to bylo někdy motivem [Gellner 1983: 60-62]. Na čem doopravdy záleží, je vyhlídka na ponížení, a na to, že budou poškozeny životy potomků. Avšak v habsburských zemích posun k nacionalismu v určitém slova smyslu nepřišel zdola. Byla to spíš touha po modernizaci státu, aby se obchod dal vyřizovat $\mathrm{v}$ jednom jazyce, která způsobila, že mobilita některých lidí směrem vzhůru byla blokována, nebo vedla př́mo dolů. Státní intervence způsobila lidovou odezvu.

15) Gellner se v „L`avvento del nazionalismo, e la sua interpretazione“ [1993] ku Hrochově argumentu kriticky vrací a poukazuje na sociální kořeny nacionalismu. Později se v této úvaze ukáže, že slabina jak Hrochovy, tak i Gellnerovy práce spočívá v nedocenění politických rozměrů nacionalismu.

16) Hrochova práce je samozřjejmě v tomto bodě vynikající.

17) John Stuart Mill, „Of Nationality, As Connected with Representative Government,“ v [Mill 1861], kapitola šestnáctá. Mazziniho nárory jsou s humorem popsány v Hobsbawmovi [nedat.], kapitoly jedna a čtyři. Srv. Alter [1990], kapitola třetí.

18) Takto čině, držím se Breuillyho [1982: 100].

19) [Taylor 1948], kapitoly pět až sedm, podává detaily i o jednotlivostech i o širším kontextu tohoto př́iběhu. 
Druhá analytická poznámka je obecnější, ale dá se k ní přistoupit tázáním se po tom, zda byli Habsburkové nacionalismem odsouzeni $\mathrm{k}$ zániku. Obecné úvahy by nás mohly vést $\mathrm{k}$ negativní odpovědi, alespoň co se týče jisté části jejich ambicí. Tím mám na mysli kremžské návrhy reformy z roku 1849, kde se v klíčovém místě píše:

„Všechny evropské národy jsou si ve svých právech rovny. Každý národ má nezcizitelné právo uchovat si a oživovat svou národnost obecně a svůj jazyk obzvlášt'. Rovnost práv ve škole, administrativě a $\mathrm{v}$ životě veřejném v místním užití je zaručena státem. “20

Kdyby toto vstoupilo $\mathrm{v}$ platnost, pak by se snad různé národy nesnažily o opuštění mocnářství. Analytickou poznámku mohu nejlépe učinit pomocí odkazu k klasickému rozlišení Alberta Hirschmanna mezi odchodem, hlasem a loyalitou: když je možné mít v systému hlas, odchod ztrácí svou přitažlivost [Hirschman 1970]. ${ }^{21}$ Jinak řečeno, záleží na povaze politického systému - nacionalismus dějinně zahrnoval separaci od autoritářské politiky. Obecný závěr je tedy povzbudivý, a to i bereme-li v úvahu problém menšin. Multinacionalismus je možný, jak naznačuje př́iklad Švýcarska, ačkoliv omezené jazykové schopnosti většiny lidí naznačují, že se jen stěží může stát pravidlem.

Habsburkové však nezvolili konzistentně tuto liberální variantu [Jászi 1961; Mann 1993, kap. 10]. Vysvětlení jejich pádu je těsně spojeno s geopolitikou. Za prvé, porážka Pruska dovolila Mad'arsku získat zpět historická práva. To, že se Mad’aři cítili ohroženi tím, že by na vlastním území nemuseli být většinou, vedlo k politice nucené mad’arizace, která zase byla hybným momentem nacionalismu jižních Slovanů [Taylor 1948: 290]. Vytvoření Rakouska-Uherska prakticky vyloučilo federální reformu. Taková reforma byla nepravděpodobná i z druhého důvodu. Habsburkové se nechtěli omezovat, opustit některá území a soustředit se na hospodářský vývoj spíše než na geopolitickou prestiž. Raison d'ętre mocnářství byl a zůstal ten, že bylo velkou mocností. Přesto se však zdá, že $\mathrm{v}$ roce 1867 císařství nevypadalo zralé na rozpad. Jeho části byly $\mathrm{v}$ nesouladu, ale geopolitická fakta stále ještě platila a Češi nevypadali na to, že by riskovali samostatnost. Porážka ve válce to vše změnila.

\section{Integrální nacionalismus}

Poslední klasický typ nacionalismu je integrální nacionalismus. Někdy je naň pohlíženo jako na reakci na Versailles, nebo obecněji jako na fenomén, který logicky následoval z předpokladu, že tlak na společenskou integraci nových národů, v té době založených, vedl k znevýhodňování menšin. V integrálním nacionalismu dochází k posunu ve stylu: je neliberální. Není v něm již místo pro přesvědčení, že lidé, mající nezcizitelná práva, potřebují ochraný krunýŕ národa - ale, že všechny národy se mohou vyvíjet v jistý celek. Naopak, zdá se, že se má za to, že univerzalismus je horečnatý výmysl: to, že by člověk měl myslet podle volání své krve, přirozeně udělalo z nacionalistických sporů záležitost darwinistickou. Etnicita plně zaujala místo občanských povinností.

Teoretikem tohoto typu nacionalismu je Ernst Nolte [Nolte 1965; srv. Alter 1990, kap. 2 a 4]. Tato forma nacionalismu tu byla př́tomná již dlouho před svou konečnou podobou, německým národním socialismem, a proto se také nedá vysvětlovat čistě jen jako reakce na Versailles. Je možné, že integrální nacionalismus je obecně živen

20) Toto je citováno v [Sked 1981]. Za mnohé vděčím tomuto článku a [Sked 1989].

21) Hirschman nedávno tvrdil, že vystoupení je ze své podstaty privátní záležitost. Nacionalismus však ukazuje, že to tak nutně být nemusí [Hirschman 1991:194]. 
traumatem porážky: rozhodně to pomáhá při vysvětlení života a činů Action Française a jejího vůdce, Maurasse, jež tento typ nacionalismu vynalezl a je jeho nejlepším prŕíladem. ${ }^{22}$ Je to však vysvětlení velmi neúplné. Víme, co chybí z vysvětlení jeho klasické formy z prrelomu století, všimneme-li si pozorně výstrahy Maxe Webera v jeho inaugurační řeči z roku 1895 :

„Musíme pochopit, že sjednocení Německa byla mladická kratochvíle, které se národ oddal ve svém věku již pokročilém; bylo by lépe, kdyby $\mathrm{k}$ němu nikdy nedošlo, protože by to byl dosti drahý přepych, i kdyby to byl jen závěr, a nikoliv začátek globální německé politiky síly.“ [Max Weber... 1978: 266; srv. Mommsen 1984]

V kontextu doby byl Weberův nacionalismus samozřejmě liberální - ačkoliv Poláci, kteří znají Weberovy názory na to, jak se měli Němci chovat na Východě v době váky, s tímto př́vlastkem zajisté nebudou souhlasit [Mommsen 1984: 211-227]. Přesto je však nutné zdůraznit, že dobový kontext tehdy zahrnoval mýtus imperialistického merkantilismu. Nově industrializované země, jakou tehdy bylo Německo, byla na vzestupu částečně díky obchodu a její budoucnost se dala zajistit tím, že se obchodních cest bude držet: byli však tací, kteř́ měli za to, že k zajištění surovinových zdrojů je nutné ovládat území. Němci se raději chovali jako „hrdinové“ než jako „obchodníci.“ [Sombart 1915; srv. Hall 1994, kap. 5] To, že Bethmann-Hollweg naslouchal takovým hlasům, přispělo k procesům vedoucím ke katastrofẽ roku 1914. ${ }^{23}$

Je zapotřebí říci něco o společenské základně integrálního nacionalismu. Studie lidových oddílů, naléhajících na expanzi na Východ a na Weltpolitik v pozdním vilémovském Německu, ukazují, že tyto názory byly přitažlivé pro vzdělané, pro ty, jejichž postup byl svázán $\mathrm{s}$ Německým státem, na nějž byli hrdí - to je fakt, který podrývá Hobsbawmův názor, že nacionalismus se stává nebezpečným ke konci devatenáctého století, protože se $\mathrm{v}$ něm začíná angažovat maloburžoazie. ${ }^{24}$ Tento úctyhodný, ale radikálně pravý nacionalismus hrál určitou roli $\mathrm{v}$ omezení manévrovacího prostoru vilémovského státu $\mathrm{v}$ letech bezprostředně předcházejících roku 1914 a přispěl tak $\mathrm{k}$ vypuknutí války. ${ }^{25}$ Pravidla diplomacie závisejí na tom, že klíčové osobnosti státu jsou zároveň členy mezinárodní společnosti: akademický realismus spočívá na existenci nadnárodní identity.To, co v té době radikální nacionalisté požadovali, byl konec nadnárodní identity, aby tak stoupla na významu společnost národní - ve světě viděném jak Sidney Webbem, tak Maurrasem či Maxem Weberem z darwinistické perspektivy.

Tento důraz na kořeny integrálního nacionalismu před rokem 1914 není zamýšlen k odvedení pozornosti od jeho zesílení po roce 1919. Je samozřejmě pravda, že mnohé z Wilsonových hranic ještě platí, ačkoliv je to z části i díky etnickým čistkám umožněným dvěma velkými revolucemi dvacátého století. Přesto si však nemůžeme neuvědomit, jak katastrofální byl vliv Versailles na střední Evropu. Byly vytvořeny režimy, které byly

22) Alter [1990: 45-46] klade důraz na význam porážky, v čemž následuje Eugena Lemberga [1964]. Prameny užívané pro Maurasse zahrnují Nolteho [1965], Eugena Webera [1962] a Michaela Curtise [1959].

23) Tento bod zvlášt’ě jasně vyzdvihnul Kaiser [1990], část čtvrtá.

24) Dvě nejdůležitější studie lidového nacionalismu jsou: Geoffre Eley [1980], a Roger Chickering [1984]. Hobsbawmova pozice je nejjasněji vyjádřena v [Hobsbawm nedat.: 118].

25) Mann [1993], kapitola dvacet. O Mannův argument se opírám i pro zbytek tohoto odstavce. Srv. Geoffre Eley [1981]. 
z geopolitického hlediska neúnosné, náchylné k vzájemným sporům a složené z menšin, jejichž útlak měl za následek nesplnitelné nároky [Holsti 1991, kap. 8 a 9; Carr 1939].

V určitém smyslu toto dalo Hitlerovi do ruky karty, s kterými se dala hrát partie rázu tak strašlivého, že nacionalismus získal pověst, z níž se již nevzpamatoval.

\section{Opakování: Od spoleènosti ke státu a režimu}

Má-li nějaké vymezení různých typů nacionalismu splnit svůj účel, to jest pomoci obecné myšlence a porozumění jednotlivých případů, pak musí být blízké historickým skutečnostem. Typologie, kterou dosud předkládám, je skutečnosti blízko a já za ní stojím, jakož i za tvrzením, že nacionalismus není jeden, ale jsou různé. Přesto však bych se rád blíže podíval na dva očividné způsoby, jimiž se dá tato typologie kritizovat. Míra nesouhlasu s druhou kritikou posune můj argument za fenomenologii a k zvýraznění klíčových teoretických problémů.

První druh kritiky je jasný. Jde o to, že by typologie měla být rozššřena. Vyčerpávající pojednání Johna Breuillyho o nacionalismu systematicky využívá nejen ,revoluce shora“, ale také rozdílu mezi separatistickým a unifikačním nacionalismem, a to u společenských jednotek majících i nemajících národní státy [Breuilly 1982]. Zatím poslední práce Ernesta Gellnera, kriticky zaměřená na porozumění nacionalismu v postkomunistických zemích, skvěle využila brilantního eseje Johna Plamenatze k poukázání na rozdíly na jedné straně $\mathrm{v}$ nacionalismu risorgimenta mezi př́ípady Německa a Itálie, které byly zcela jasně na vysoké kulturní úrovni, a situací dále na východ, kde kultury byly takřka úplně vynalezeny, na straně druhé. ${ }^{26}$ Jemnější rozbor by také plynul z jasnějšího rozlišování mezi náladami lidu, sny intelektuálů a manipulativními praktikami politiků. ${ }^{27}$ Platnost a užitečnost rozdílů však není taková, že by nemohly být zahrnuty do zde předložené typologie, kdyby bylo k vypracování poskytnuto více prostoru.

To, že typů je tolik, může vyprovokovat opačnou námitku, trochu v Pirandellově duchu, zhruba ř́kající, že tyto typy by měly být zahrnuty pod nějakou obecnou integrující teorii. Obávám se, že toto by byla námitka Ernesta Gellnera. Je to proto také dobrá př́ležitost $\mathrm{k}$ návratu $\mathrm{k}$ jeho teorii. $\mathrm{V}$ podstatě není těžké uvidět, jak by se dalo množství trríd zmenšit. Určitého výsledku se dá dosáhnout tak, že se rozširíi pojem nacionalismu ve vývoji industrialismu, a tak se zahrne kapitalistický vývoj, který dodal materiál pro nacionalismus risorgimenta. Ještě lepší, podle mého názoru, by bylo vzít pojem omezené možnosti pohybu, chápaný jako určité ponížení, a říci, že to je jedna ze základních složek vývoje průmyslu. ${ }^{28}$ Tato linie je v základu Gellnerova nejlepšího a opravdového pokusu o vytvoření obecné teorie nacionalismu - to jest druhé a obecnější teorie, která netrpí funkcionalismem typu školy průmyslové společnosti, k níž se Gellner v určité míře

\footnotetext{
26) [Plamenatz 1976]. O tomto eseji pojednává Gellnerův článek „L’avvento del nazionalismo, e la sua interpretazione." [Gellner 1993] Gellnerovy argumenty se velmi podobají argumentům Theodora Schiedera z práce Der Nazionalstaat in Europa als Historisches Phänomen.

27) Za tento nápad vděčím Włodkovi Wesołowskému.

28) Ponížení je také s určitostí částí latinskoamerického nacionalismu, který však postrádá modernizační impuls. Obchodní nacionalismus, níže diskutovaný, je také náchylný k poukazování na takové pocity, přestože jeho vnější forma se zdá více věcná.
} 
přiklání. ${ }^{29}$ Přesněji řečeno, toto spojení je pro něj důležité, protože jinak by se tento způsob vývoje průmyslové společnosti mohl odehrávat i ve velkých impériích: nemusel by na sebe brát formu nacionalismu. Činitelé v této kategorii se snaží modernizovat nezávisle na metropolích, které potlačují jejich vlohy, a někdy i proti nim. Tímto chci říci, že se Gellner zabývá svým českým původem, tak jako i zkušeností ze severní Afriky, a že byl $\mathrm{v}$ tomto bodě neprávem kritizován, byl-li považován jen za teoretika vývoje průmyslu.

Smysl tohoto typu integrujícího argumentu je jasný, a mám na mysli i další důvody proč se vyhýbat dogmatismu ohledně mých vlastních pojmů. Za prvé, je nám nyní jasné, že typy znázorňují do jisté míry stadia, s tou výhradou, že např́iklad vývoj nespolečenské společnosti je ojedinělý a dále ho nepouživám. Za druhé, brzo možná uvidíme, že integrální nacionalismus v současném světě ztrácí své ostř́í, protože jeho snaha o etnickou homogenitu nemusí být svázána s ekonomickým merkantilismem - ani se nezmocňuje snadno politiků natolik, že by byli nuceni nebrat $\mathrm{v}$ úvahu skutečnost nadnárodního společenství. Přesto však nemám za to, že by vývoj nespolečenské společnosti, revoluce shora, touha a strach posvěcené př́ležitostí a integrální nacionalismus unikly integrujícímu argumentu výše naznačenému. ${ }^{30}$ Dávám přednost svým typům nacionalismu na fenomenologickém základě: mými př́klady jsou velmi různorodí lidé a myslím, že by se v jedné společnosti necítili př́iliš př́ijemně. Není však ani záhodné, ani nutné nechat věci tak, jak jsou. Dají se vysledovat určité rysy společné všem představeným typům: výklad se zakládal více na faktorech politických, zabývajících se státem a režimem, než na faktorech společenských.

Můžeme začít tím, že zdůrazníme, že Gellnerův trinitární pohled na dějiny lidstva je př́liš jednoduchý: je př́lilš ekonomickým materialistou, takřka inverzním marxistou, ve své představě, že dějiny jsou strukturovány jednoduše vývojem od sběračství a lovu, přes zemědělství až $\mathrm{k}$ modernímu průmyslu - ačkoliv i tyto síly byly bezesporu mocné [Gellner 1988]. Přesněji řečeno, jsou dva způsoby, jimiž se novověk dá vidět jako předzvěst moderního průmyslu. Za prvé, v Británii se rozšířily vztahy občanské společnosti $\mathrm{v}$ důsledku obchodní revoluce, která předznamenala příchod epochy průmyslu. Za druhé, multipolární soutěž států vznikla v epoše agrární a přelila se i do éry průmyslu: ${ }^{31}$ nebyla to nikdy jen nadstrukturní záležitost, schopní ovlivňovat a utvářet dějiny hospodářství a společnosti. ${ }^{32}$ Nacionalismu jasně záleželo na státech. Dlouhým procesem se vytvořily v severozápadní Evropě národní státy a územně zakotvené společenské vztahy. Snad ještě významnější byly fiskální potřeby států, stále válčících, které vedly k touze po repre-

29) Tato obecná teorie je nejlépe podaná v Gellnerově Thought and Change [1964], kteroužto knihu pokládám obecně vzato za přesvědčivější než jeho pozdější Nations and Nationalism [1983].

30) Výjimečný esej Perry Andersona [nedat.], „Science, politics, disenchantment“, srovnává Gellnerův a Weberův přístup $\mathrm{k}$ nacionalismu a dospívá k závěru, že Gellnerův přístup je esenciálně funkcionalistický a neobjasňuje hrozivost, ke které má nacionalismus sklon, jako integrální část jeho definice.

31) Toto je jesně formulováno Anthony Wrigleym [1988]. Sociologie nacionalismu Benedicta Andersona se od Gellnerovy liší v tomto: záleží mu na nástupu tištěné kultury spíše než na vzestupu průmyslu per se.

32) Pro kritiku Gellnera v tomto bodě viz John A. Hall [nedat]. 
zentaci, která pak povzbudila národní cítění. Síly občanské společnosti, ponechané samy sobě, nemají tendenci k politickým činům. Záleží na jejich propojení se zájmy státu.

Povaha režimu má však alespoň tak velký dopad jako stát. Víme, že pracující třídy se na přelomu století lišily v úrovni militantnosti v závislosti na režimech, s nimiž přicházely do styku: prrítomnost liberálního režimu měla za následek, že třídní konflikt byl spíš průmyslové než politické povahy, zatímco politické znemožnění autokracie a autoritářství soustředovalo pozornost na stát jednak pro jeho despotickou povahu, jednak protože nedovoloval vytváření odborů. ${ }^{33}$ Max Weber si tohle brzy uvědomil, a proto požadoval omezení vilémovského autoritářství. Ani kapitalisté, ani stát se nemusel nikterak obávat liberálního postupu vůči pracující třídě: čím více se tato třída cítila částí společnosti, tím méně pravděpodobná byla její radikalizace. ${ }^{34}$ Stejný paradoxní princip že otevřenost zvyšuje př́íchylnost - platí i o nacionalismu. ${ }^{35}$ Obecná definice podaná na začátku pečlivě zaznamenala, že kulturní nacionalismus má tendenci se politizovat. Vlastně jsme viděli, že liberální varianta byla po ruce na habsburských územích. Kdyby byla bývala přijata, pravděpodobně by uspokojila rozhodující národy tím, že by respektovala jejich historická práva. Nacionalismus se nemusel zpolitizovat. Habsburkové tuto možnost vyloučili, protože byli přesvědčení, že federalismus by podryl jejich geopolitické ambice. Mám ten dojem, že se v tomto bodě mýlili, stejně jako vilémovští politici, kteří si nepovšimli, že jejich pracující třída by se dala nejlépe kooptovat za pomocí reformy. Posílilo by se mocnářství přijetím liberální varianty, jak si myslel Masaryk? Očividně na tuto otázku nemůžeme odpovědět. Můžeme všemožně podpořit přijetí etiky teoretiků osmnáctého, spíše než devatenáctého století: politická libovůle vytváŕí mnohem více vzteku než společenská nerovnost. Lidé dávají přednost reformě před revolucí, možnosti mírové změny před nástrahami barikád.

\section{Novodobé varianty}

S první novodobou variantou jsme se již setkali jakožto $s$ vývojem průmyslu, ale rozbor dopadu Spojených států $\mathrm{v}$ rámci jejich sféry vlivu $\mathrm{v}$ poválečné době může dále pomoci porozumění jeho povahy. Dekolonizující nacionalismus byl do jisté míry zakotven $\mathrm{v}$ americké nechuti vůči evropským mocnostem, která pramenila z ideologických a ekonomických důvodů. Toto jasně uspíšilo zánik kolonií Holandského království, a nebylo to bez vlivu ani $\mathrm{v}$ príṕpadu Británie. Nicméně, logika situace si vyžadovala dekolonizaci. Impérium se stávalo nákladným v okamžiku, kdy bylo nutné užívat evropských vojenských jednotek, což byl př́pad i poměrně malých povstání. Britové, jakmile ztratili indickou armádu, toto pochopili takřka okamžitě a předali území skupinám, o jejichž nárocích zastupovat „národ“ často věděli, že jsou prostě směšné. Oproti tomu Francouzi bojovali déle a úporněji a dokonce snili i o větší Francii, v jejímž rámci by byla umožněna modernizace. Jedno $\mathrm{z}$ nejpůsobivějších a nejvlivnějších logických cvičení Raymonda Arona - dokazující, že taková politika by vedla k podstatnému snížení životní úrovně v samotné Francii - prakticky tuto iluzi ukončilo [Aron 1957]. I přesto následné osudy těchto nových států byly hluboce ovlivněny podmínkami

33) K tomto tématu je velké množství literatury. Viz, mezi jiným, i [Geary 1984, McKibbin 1990, Mann 1993, Katznelson and Zolberg 1987 a McDaniel 1988].

34) Weber své názory vyjářil zvláště jasně ve válečných poznámkách $\mathrm{k}$ historické sociologii vilémovského Německa [Weber 1978: 1391].

35) Tento postřeh je centrální v [Mann 1993]. 
amerického systému. Světová velmoc byla po většinu poválečného období mimořádně konzervativní. Zcela mimořádná pocta byla vzdávána normám suverenity, což mělo za důsledek, že velmi málo hranic bylo posunuto; jestliže Spojené státy tyto normy dodržovaly, pak to samozřejmě bylo i k užitku samotných postkoloniálních států. Tímto nechci popírat, že Spojené státy se někdy srovnávaly se postkoloniálním světem dost uboze. Pravidla mezinárodního trhu, na nichž trvaly, pomáhaly mnohem více zemím již rozvinutým než rozvojovým [Ruggie 1982]. Důležitější ale je, že Spojené státy byly náchylné $\mathrm{k}$ potlačování nacionalismu, jako by to byl komunismus. Proto uvízly ve Vietnamu a smírily se raději s Ajatolláhem Chomejním než s Mossadekem. Přesto se dá v širším dějinném kontextu říci, že Spojené státy mají raději obchod než hrdinství a že jejich impérium je nyní takřka výhradně neteritoriální. Volně řečeno, třetí svět je spíše přehlížen než vykořistován.

To, že Spojené státy byly a jsou jasným a jediným hegemonem kapitalistické společnosti, mělo rozhodující dopad na státy vyspělého světa [Hall 1994, kap. 3 a 4]. Obchod zcela běžně vystřídal hrdinství, ekonomické ambice váží víc než geopolitické sny. Některé merkantilistické triky se ještě praktikují Japonskem a $\mathrm{v}$ těchto dobách nejistoty ještě více Evropským společenstvím, ale jsou to více těžkosti politické ekonomie našeho světa než katastrofy hrozící jej pohltit. Situace je přesně opačná než mezi válkami: podstatná stabilita geopolitického uspořádání umožňuje mnohé kompromisy ve sféře ekonomické. Je snad možné, že tento postupný zánik ekonomického imperialismu zamezí oživení integrálního nacionalismu, ale je také nepochybné, že americký systém přispěl i internacionalizaci klíčových elit - které již rozhodně nejsou omezovány nacionalistickými nátlakovými skupinami. Ale soustředění na zavedené státy by se nemělo přehánět, aby neodvedlo naši pozornost od konečného a zásadně nového druhu nacionalismu, to jest od nacionalismu obchodního. Nejodvážnějším teoretikem tohoto typu je Tom Nairn, ale i nedávné argumenty Hudsona Meadwella ukazují stejným směrem [Nairn 1977, Meadwell 1993]. Tento obchodní nacionalismus je nový tím, že se snaží o separaci vyspělých oblastí. Nairn zdůraznuje, že tento nacionalismus má velkou šanci na úspěch tehdy, když je pravděpodobné, že daný region bude ekonomicky prosperovat: tak např́klad šest hrabství Severního Irska si nijak nepřeje být ochuzeno spojením s chudými katolickými rolníky, a podobně španělští Baskové a snad i severní Itálie si přejí chránit své ekonomické zájmy. Představitelem tohoto typu nacionalismu je vůdce Parti Québecois, Jacques Parizeau, jehož strategie spočívá v přesvědčování quebečanů, že by se jim bez zbytku Kanady vedlo lépe. Pravděpodobný úspěch tohoto typu nacionalismu se dá jen těžko předvídat. Viděli jsme jen velmi málo států, které by opustily liberální systém, a zmenšená geopolitická potřeba centralizovaných a unitárních států umožňuje zavedení federálního uspořádání či zrrízení zahrnujícího různé společnosti, čímž se zmenší možná nespokojenost $\mathrm{s}$ daným stavem. ${ }^{36}$ Toto se snad podařilo ve Španělsku, ale určitě ne ve Skotsku, kde neexistence místního sněmu měla za následek, že většině obyvatel po léta vládli lidé nepocházející ze stejné kultury. Ale ekonomické změny mohou zvýšit šance takového nacionalismu na úspěch tím, že se zmenší náklady, které by s sebou taková změna přinesla. Jestli má pravdu Adam Smith, pak zmenšení velikosti trhu zvyšuje blahobyt: když je možné separovat se a zůstat přitom zapojen do širšího trhu, tak jako se to děje v Evropě, ale zatím nikoliv v Africe, pak obchodní nacionalismus začíná vypadat slibně. Ale i když se toto děje, je důležité si uvědomit, že to

36) Za toto vděčím Michaelu Mannovi. 
nemá obecný a zásadní význam. Zdá se nepravděpodobné, že by politická demokracie a otevřený trh mohly být tímto typem nacionalismu ohroženy.

Žádný přehled nacionalismu nemůže nezmínit dvě nastávající situace - jednu zjevnou, ale druhou potenciálně snad ještě významnější, které jsou těžko pochopitelné a ze kterých by mohl vzejít nový typ nacionalismu. Před první z těchto situací je postaven postkomunistický svět, před druhou mnohé z postkoloniálních států.

Při pohledu do minulosti je zřejmé, že bolševici pokračovali v práci carů a oddálili tak budování národa, které je proto nyní mnohem vyhrocenější a rozhodnější. Postkomunistická situace je složitá a zdá se být pozoruhodnou směskou starých a nových faktorů. Je mnoho pravdy na tom, že nacionalismus se v této části světa, zvláště pak v Jugoslávii, stane velmi nebezpečný. Uvědomme si, že národy tam byly tvořeny ab initio, to jest spíš z rolnické základny než na základě již vyspělé kultury. Národy bývalého Sovětského svazu byly vždy náchylné k nacionalismu, protože imperiální systém, který jim vládnul, byl veden Rusy - jejichž plenění se netýkalo jen sféry politické a hospodářské, ale i ekologické [Khazanov 1993]. Tyto dva př́klady jsem vyzdvihnul, abych zdůraznil, že známý argument Juana Linze a Alfreda Stepana, že včasné volby by bývaly zabránily rozpadu Sovětského svazu a Jugoslávie, tak jako mu zabránily ve Španělsku, je prostě přehnaný [Linz and Stepan 1992]. Je zajisté pravda, že ani Gorbačov ani Miloševič nevzali v úvahu potřebu okamžitých voleb, ale tito autoři nechápou závažnost př́spěvku nenávisti. Nevidí zásadní a podstatný rozdíl mezi liberalizačním úsilím $\mathrm{v}$ socialismu a $\mathrm{v}$ kapitalismu. Liberalizace má mnohem menší šanci na úspěch v socialistických společnostech, protože v nich je velmi poničená struktura občanské společnosti [Bova 1991: 131-132]. Je vždy velmi pravděpodobné, že vakuum vzniklé zánikem socialistického záměru bude vyplněno nacionalismem. Je-li toto jedním novým rysem nacionalismu $\mathrm{v}$ postkomunistických společnostech, pak druhým je povaha některých vůdců. Je velmi nápadné, že bývalí komunisté neschopní úspěchu na trhu byli a jsou přitahováni nacionalismem na základě vlastního zájmu. Člověk má dojem, že Vladimír Mečiar, slovenský premiér, někdy stě̌zi mohl věřit lstem, jichž sám používal.

Osud velké části světa zůstává otevřen. Původní skupina nástupnických států Sovětského svazu se zakládá na bývalých svazových republikách. Samožrejmě je velmi lehké poukázat na možnosti matrjoškového nacionalismu, to jest na proces, v němž jsou doposud úspěšné nové národní jednotky vystaveny separatistickým nárokům - takový proces by byl zřejmě nekonečný [Bremmer and Taras 1993, Szporluk 1992, National... 1992, Khazanov 1991 a „A Country...“ 1993]. To, že tato varianta vypadá nejpravděpodobněji na severním Kavkazu, může mít souvislost s jasným integrálním nacionalismem Gruzie [Jones 1993]. Oproti tomu je matrjoškový nacionalismus v Rusku poněkud omezen Jelcinovým př́klonem $\mathrm{k}$ demokracii: touha tuto cestu opustit je zdržována možností vyjádřit se. I tento faktor vysvětluje pozoruhodný úspěch Ukrajiny, která zahrnuje různá náboženství, jazyky i etnika v rámci jednoho státu [Krawchenko 1993]. Tato úvaha nás vede k závěrečné úvaze. Umírněná, federálnější a demokratičtější cesta je umožněna tím, že geopolitické rozpory byly omezeny a pod kontrolou již od konce druhé světové války. Kdyby se Rusko přiklonilo k hrdinství, pak by podpora mocností byla naprosto nutná. Takové státy by nebraly velké ohledy na potřeby svých vlastních menšin.

Zde nastíněné úvahy nás přivádějí k rozboru postkoloniální situace. Anthon Smith zajisté právem zdůraznuje, že budování národa a státu bylo a je v postkoloniálních státech 
často velmi obtížné [Smith 1986b]. Nemusíme přijímat jeho kladné tvrzení - že evropské národy závisely na jednotném etnickém základě - abychom se přiklonili k náhledu, že neexistence sdílených politických dějin a existence tribalismu představují velký problém. Mimořádná stabilita, která byla následkem respektování zásady nevměšování - které se držely africké státy i za cenu přijetí Idi Amina - má již na kahánku. Přijetí této zásady mělo za následek mimořádně malé množství válek mezi státy třetího světa po roce 1945 což nikterak nesnižuje počet civilních obětí občanských válek [Holsti 1993]. Následkem tohoto stavu je, že státy se často spokojovaly s pasivním ovládáním rozličných složek a nesnažily se pochopit jejich společnosti. Ve strašném slova smyslu země třetího světa neválčily dost, nebo alespon nevedly dost válek toho správného typu. Jsou to pseudospolečnosti, ne národní státy [Jackson 1990]. Velmi potřebují posílení, aby mohly zavést základní pořádek, který my již máme za samozřejmost.

Tato úvaha naznačuje znepokojivý závěr. Vypadá to jako by se chystala změna světového řádu. Ze zásad suverenity a nevměšování se poněkud slevuje a je možné, že pravidla intervence, umožněná úmluvou velmocí, přicházejí na scénu. $Z$ jedné strany je nutné to uvítat: díky nim se libaralismus stává reálnějším. Na straně druhé to ale nemusí být až tak skvělé. Je mnoho menšin, jejichž osud volá po zásahu: nejen bosenští Srbové, Palestinci a Kurdové, ale, podle jednoho nedávného výzkumu, i dalších alespoň 250 menšin je v současnosti ohroženo [Gurr and Scarritt 1989]. ${ }^{37}$ Kdyby se jim všem mělo umožnit utvoření národního státu, počet států na světě by se zdvojnásobil. Kromě toho mějme na paměti, že na světě je přinejmenším osm tisíc jazyků, z nichž většina by se dala využít pro nacionalistické nároky [Gellner 1983]. Bereme-li za bernou minci, že ne každý jazyk může mít stát, pak bychom měli uvažovat o rozumnosti strategie intervence, která může oslabit státy, které by měly být posíleny. Naštěstí máme kam se obracet pro poučení: rozpad Jugoslávie nás učí, že mezinárodní uznání státu by mělo přijít až v okamžiku, kdy tento zaručí mezinárodně přijatelná práva menšinám na svém území. Genscher toto v př́padě Chorvatska neučinil. Ale to je jen jeden problém. Dilema jako celek - mezi univerzálním liberalismem a zakládáním států, jejichž vytvoření může být nadějí pro celé lidstvo - je př́liš složité, než abych ho, alespoň v této chvíli, mohl vyřešit.

Přeložila Anna Pilátová

JOHN A. HALL je profesorem sociologie na McGill University v Montrealu v Kanadě. Jako historický sociolog se specializuje na stát a nyní se zabývá především problémy nacionalismu. Je autorem studii Powers and Liberties (1986), Liberalism (1988) a Coercion and Consent (1994). Tento esej byl prednesen $k$ osmdesátinám Barringtona Moora a otištěn v časopisu Americké akademie uméni a véd Dćdalus, vol. 122, no. 3 v létě 1993 s laskavým svolením autorovým.

\section{Literatura}

Abercombie, Nicolas, Stephen Hill, Brian Turner 1988. Sovereign Individuals of Capitalism. Londýn: Allen a Unwin.

„A Country of Countries.“ 1993. The Economist, 27. března 1993.

Alter, Peter 1990. Nationalism. London: Edward Arnold.

Anderson, Benedict 1983. Imagined Communities. London: Verso.

Anderson, Benedict 1991. Imagined Communities. rev. ed. London: Verso.

37) Tento přehled je citován Holstim [1993]. 
Anderson, Perry nedat. „Science, politics, disenchantment.“ In Transitions to Modernity, ed. by Hall and Jarvie.

Armstrong, John 1982. Nations before Nationalism. Chapel Hill, NC: University of North Carolina Press.

Aron, Raymond 1957. La tragédie algérienne. Paris: Plon.

Bethell, L. (ed.) 1987. The Independence of Latin America. Cambridge: Cambridge University Press.

Blanning, T. C. W. 1983. The French Revolution in Germany: Occupation and Resistance in the Rhineland, 1792-1802. Oxford: Clarendon Press.

Bova, Russell 1991. „Political Dynamics of the Post-Communist Transition: A Comparative Perspective, “ World Politics 44.

Bremmer, Ian, Ray Taras (ed.) 1993. Nations and Politics in the Soviet Successor States. Cambridge: Cambridge University Press.

Breuilly, John 1982. Nationalism and the State. Manchester: Manchester University Press.

Brewer, John 1972. Party Ideology and Popular Politics at the Accession of George III. Cambridge: Cambridge University Press.

Carr, Edward Hallett 1939. The Twenty Years Crisis, 1919-1939. London: Macmillan \& Co.

Chickering, Roger 1984. We Who Feel Most German. Boston, MA: Allen \& Unwinn.

Clausewitz, Carl von 1976. On War. (přel. Michael Howard a Peter Paret) Princeton, NJ: Princeton University Press.

Colley, Linda 1992. Britons: Forging the Nation 1707-1837. New Haven, CT: Yale University Press.

Crone, Patricia 1990. Pre-Industrial Societies. Oxford: Basil Blackwell.

Curtis, Michael 1959. Three Against the Third Republic. Princeton, NJ: Princeton University Press.

Eley, Geoffre 1980. Reshaping the German Right. New Haven, CT: Yale University Press.

Eley, Geoffre 1981. „Some thoughts on the nationalist pressure groups in Imperial Germany.“ In Nationalist and Racialist Movements in Britain and Germany before 1914, ed. by Paul Kennedy and Anthony Nicholls. London: Macmillan.

Geary, Dick 1984. European Labour Protest 1848-1945. London: Methuen \& Co.

Gellner, Ernest 1964. Thought and Change. London: Weinfield \& Nicholson.

Gellner, Ernest 1973. „Scale and Nation.“ Philosophy of Social Sciences 3.

Gellner, Ernest 1983. Nations and Nationalism. Oxford: Basil Blackwell.

Gellner, Ernest 1988. Plough, Sword and Book. London: Collins Harvill.

Gellner, Ernest 1991. „Nationalism and Politics in Eastern Europe.“New Left Review 189.

Gellner, Ernest 1992. „Nationalism reconsidered and E. H. Carr.“ Review of International Studies 18.

Gellner, Ernest 1993. „L'avvento del nazionalismo, e sua interpretazione. I miti della nazione e della classe.“ In Storia d'europa, ed. Perry Anderson. Torino: Einaudi.

Greenfeld, Liah 1992. Nationalism. Cambridge, MA: Harvard University Press.

Gurr, Ted Robert, James R. Scarritt 1989. „Minority Rights at Risk: A Global Survey.“ Human Rights Quarterly 11.

Hall, John A. nedat. „Peace, peace at last?.“ In Transitions to Modernity, ed. by Hall and Jarvie.

Hall, John A. 1985. Powers and Liberties. Oxford: Basil Blackwel.

Hall, John A. 1993. „Understanding States.“ In The State, ed. by John A. Hall. London: Routledge. 
Hall, John A. 1994. International Orders. Oxford: Polity Press. (v tisku)

Hintze, Otto 1975. „Military Organization and the Organization of the State.“ In The Historical Essays of Otto Hintze, ed. by Felix Gelbert. Princeton, NJ: Princeton University Press.

Hirschman, Albert 1970. Exit, Voice and Loyalty. Cambridge, MA: Harvard University Press.

Hirschman, Albert 1991. „Exit, Voice and the Fate of the German Democratic Republic: An Essay in Conceptual History." World Politics 45.

Hobsbawm, Eric nedat. Nations and Nationalism since 1780. Cambridge: Cambridge University Press.

Holsti, Kalevi J. 1991. Peace and War. Cambridge: Cambridge University Press.

Holsti, Kalevi J. 1993. „Armed Conflicts in the Third World: Assessing Analytical Approaches and Anomalies.“ Přednáška přednesená na McGill University v březnu 1993.

Hroch, Miroslav 1985. The Social Preconditions of National Revival in Europe. Cambridge: Cambridge University Press.

Jackson, Robert H. 1990. Quasi-states: Sovereignity, International Relations, and the Third World. Cambridge: Cambridge University Press.

Jászi, Oszkar 1961. The Dissolution of the Habsburg Monarchy. Chicago, IL: Chicago University Press.

Jones, Stephen 1993. „Georgia: a failed democratic transition.“ In Nations and Politics in the Soviet Successor States, ed. by Ian Bremmer, Ray Taras. Cambridge: Cambridge University Press.

Kaiser, David 1990. Politics and War, Part three. Cambridge, MA: Harvard University Press.

Katznelson, Ira, Aristide Zolberg (ed.) 1987. Working Class Formation. Princeton, NJ: Princeton University Press.

Khazanov, Anatoly 1991. Soviet Nationality Policy During Perestroika. Virginia: The University Press of Virginia.

Khazanov, Anatoly 1993. „The Collapse of the Soviet Union.“ Nationalities Papers (v tisku).

Krawchenko, Bogdan 1993. „Ukraine: the politics of independence.“ In Nations and Politics in the Soviet Successor States, ed. by Ian Bremmer, Ray Taras. Cambridge: Cambridge University Press.

Lemberg, Eugen 1964. Nationalismus. Reinbek bei Hamburg:Rowohlt.

Linz, Juan J., Alfred Stepan 1992. „Political Identities and Electoral Sequences: Spain, the Soviet Union, and Yugoslavia." Daedalus 121.

Lynch, John 1973. The Spanish-American Revolutions: 1808-1826. New York: W. W. Norton.

Lynch, John 1987. „The origins of Spanish Americal independence.“ In The Independence of Latin America, ed. by L. Bethell. Cambridge: Cambridge University Press.

Mann, Michael 1984. „The Autonomous Power of the State: Origins, Mechanisms and Results.“ European Journal of Sociology 25.

Mann, Michael 1986. Sources of Social Power, Volume One: From the Beginning to A.D. 1760. Cambridge: Cambridge University Press.

Mann, Michael 1992. „The Emergence of modern European nationalism.“ In Transition to Modernity, ed. by John A. Hall and Ian Jarvie. Cambridge: Cambridge University Press.

Mann, Michael 1993. Sources of Social Power, Volume two: The Rise of Modern Nations and Classes, 1760-1914. Cambridge: Cambridge University Press.

Masur, Gerhard 1969. Simon Bolivar. Albuquerque, NM: University of New Mexico Press.

Max Weber: Selections in Translation 1978. Ed. by Walter Garrison Runciman. Cambridge: Cambridge University Press. 
Mayal, James 1990. Nationalism and International Society. Cambridge: Cambridge University Press.

McDaniel, Tim 1988. Capitalism, Autocracy and Revolution. Berkeley, CA: University of California Press.

McKibbin, Ross 1990. The Ideologies of Class. Oxford: Oxford University Press.

Meadwell, Hudson 1993. „The Politics of Nationalism of Quebec.“ World Politics 45.

Merquior, José 1981. „Politics of Transition.“ Government and Opposition 16.

Mill, John Stuart 1861. Representative Government. London: Oxford University Press.

Mommsen, Wolfgang 1984. Max Weber and German Politics 1890-1920. Chicago, IL: University of Chicago Press.

Mommsen, Wolfgang 1990 „Varieties of the Nation State in Modern History: Liberal, Imperialist, Fascist and Contemporaty Notions of Nation and Nationality." In The Rise and Decline of the Nation State, ed. by Michael Mann. Oxford: Basil Blackwell.

Moore, Barrington 1966. The Social Origins of Dictatorship and Democracy. Boston, MA: Beacon Press.

Nairn, Tom 1977. The Break-up of Britain. London: New Left Books.

National Processes in the USSR: Problems and Trends. 1992. USSR Academy of Sciences. Moscow: Nauka.

Nolte, Ernst 1965. Three Faces of Fascism. New York: Holt, Rinehart and Winston.

O'Boyle, Linda 1970. „The problem of an excess of educated men in Western Europe, 18001850.“ Journal on Modern History 42.

Paret, Peter 1976. Clausewitz and the State. Princeton, NJ: Princeton University Press.

Pederson, Susan 1991. „National Bodies, Unspeakable Acts: The Sexual Politics of Colonial Policy Making." Journal of Modern History 63.

Plamenatz, John 1976. „Two Types of Nationalism.“ In Nationalism: The Nature and Evolution of an Idea, ed. by Eugene Kamenka. London: Edward Arnold.

Ruggie, John G. 1982. „International regimes, transactions and change.“ International Organizations 36.

Schama, Simon 1977. Patriots and Liberators. New York: Alfred A. Knopf, Inc.

Schieder, Theodor 1964. Der Nazionalstaat in Europa als Historisches Phänomen. Cologne: Westdeutscher Verlag.

Sked, A. 1981. „Historians, the nationality question and the downfall of the Habsburg Empire.“ Transactions of the Royal Historical Society 31.

Sked, A. 1989. The Decline and Fall of the Habsburg Empire 1815-1918. London: Longman.

Smith, Anthony D. 1984. „Ethnic persistence and national transformation.“ British Journal of Sociology 35.

Smith, Anthony D. 1986a. The Ethnic Origin of Nations. Oxford: Basil Blackwell.

Smith, Anthony D. 1986b. „State-Making and Nation-Building.“ In States in History, ed. by John A. Hall. Oxford: Basil Blackwell.

Sombart, Werner 1915. Händler und Helden. Leipzig: Duncker und Humblot.

Staniszkis, Jadwiga 1991. The Dynamics of the Breakthrough in Eastern Europe. Berkeley, CA: University of California Press.

Strange, Susan 1987. „The Persistent myth of lost hegemony.“ International Organisation 41.

Szporluk, Roman 1992. „The National Question.“ In After the Soviet Union, ed. by Timothy J. Colton and Robert Legvold. New York: W. W. Norton \& Co.

Taylor, Alan J. P. 1948. The Habsburg Monarchy 1809-1918. London: H. Hamilton. 
Tilly, Charles 1990. Coercion, Capital and European States, A.D. 990-1990. Oxford: Basil Blackwell.

Watkins, Susan Cotts 1991. From Provinces into Nations. Princeton, NJ: Princeton University Press.

Weber, Eugen 1962. Action Française. Stanford, CA: Stanford University Press.

Weber, Eugen 1979. Peasants into Frenchmen. London: Chatto \& Windus.

Weber, Max 1978. „Parliament and Government in a Reconstructed Germany.“ In Max Weber, Economy and Society, přel. G. Roth a C. Wittich. Berkeley, CA: University of California Press.

Wrigley, Anthony 1988. Continuity, Chance and Change. Cambridge: Cambridge University Press.

Zhao, Den-xin, John A. Hall 1993. „State Power and Patterns of Late Development,“ Sociology. 